Chirurgia (2020) 115: 486-492

No. 4, July - August

Copyright@ Celsius

http://dx.doi.org/10.21614/chirurgia.115.4.486

\title{
Burns in the Emergency Department: A One-Year Single Center Analysis on 355 Cases
}

\author{
Vlad Pieptu' ${ }^{1}$ Alexandru Mihai', Costin Groza², Corneliu Gheorghiță², Diana Cimpoieșü ${ }^{3 *}$, Doina Azoicăi \\ 1Department of Plastic and Reconstructive Surgery, Grigore T. Popa University of Medicine and Pharmacy lași, Romania \\ ${ }^{2}$ Department of Epidemiology, Grigore T. Popa University of Medicine and Pharmacy lași, Romania \\ ${ }^{3}$ Department of Emergency Medicine, Grigore T. Popa University of Medicine and Pharmacy lași, Romania
}

*Corresponding author: Professor Diana Cimpoieșu Department of Emergency Medicine, Grigore T. Popa University of Medicine and Pharmacy lasi, Romania E-mail: dianacimpoiesu@yahoo.com

\section{Rezumat}

Arsurile în unitățile de primire urgențe: o analiză unicentrică a 355 cazuri pe durata unui an

Introducere: Arsurile sunt o cauză frecventă de prezentare la unitățile de primire urgențe. Deşi arsurile extensive sau speciale necesită tratament în centre specializate, majoritatea pot fi îngrijite ambulator sau în secții chirurgicale. România deține un mecanism național de colectare a datelor spitalizărilor, însă nu sunt disponibile statistici privind cazurile de arsuri ne-spitalizate. Acest studiu explorează amplitudinea fenomenului arsurilor analizând date ce corespund unui an calendaristic, la cea mai mare Unitate de Primire Urgențe din Regiunea de Nord-Est a României. Metode: Acesta este un studiu retrospectiv pe un an de zile al tuturor prezentărilor pentru arsuri în Unitatea de Primire Urgențe de la Spitalul Sf Spiridon Iaşi, pentru anul 2015. Au fost incluse toate etiologiile de arsuri.

Rezultate:Au fost analizate 355 de cazuri. Numărul mediu lunar de cazuri a fost de 29,58, cu un maxim de 54 şi un minim de 18 . Au fost 206 bărbați şi 149 femei, cu o pondere urbană de 57,7\%. Doar 134 de cazuri au fost spitalizate în această perioadă.

Concluzii: Aproape 2/3 din cazuri nu au fost spitalizate, astfel lipsind din statisticile naționale. Date epidemiologice precise sunt extrem de importante pentru o strategie națională de management pentru arsuri. Se sugerează crearea unui registru național de arsuri.

Cuvinte cheie: arsuri, epidemiologie, registru de arsuri, traumatologie arsuri, medicină de urgență 


\begin{abstract}
Background: Burns are common reasons for emergency department presentations. While extensive or special burns require treatment in a specialized center, the majority are amenable to ambulatory treatment or hospitalization in a surgical ward. Romania has a national data collecting mechanism regarding all hospitalized patients, but there are no available statistics concerning non-hospitalized burn cases. This study aims to explore the amplitude of burn trauma by analyzing data from an Emergency Department at a major Romanian regional trauma center.

Methods: This is a retrospective single-center 1-year study of all burn-related emergency department presentations at the trauma referral center for Romania's North-East region, in 2015. Included in the study were all cases of burns, indiscriminate of their etiology.

Results: A total of 355 burn cases were analyzed. The average monthly number of cases was 29.58 , with a maximum of 54 and a minimum of 18. There were 206 males and 149 females and 57.7\% urban residents. Only 134 cases have been hospitalized during this period.

Conclusion: Almost two-thirds of cases have not been hospitalized, thus missing from national statistics. Precise epidemiological data is paramount for a successful national burn management strategy. Creation of a national burn registry is suggested.
\end{abstract}

Key words: burns, burn epidemiology, burn registry, burn trauma, emergency medicine

\section{Introduction}

Burns are a common cause of emergency department presentations and one of the most frequent causes of acute death (1). These types of injuries require a multidisciplinary approach and usually result in long hospitalization and rehabilitation treatments, with important morbidity and mortality and a significant impact on quality of life. In Europe there are an estimated 7.4/100,000 annual burn-related deaths (2-4). Worldwide the number of deaths due to burn injuries each year varies from almost 322.000 in $2002(5,6)$ to 180.000 in 2018 (7).

The treatment of burn patients has always been an example of multidisciplinary team approach (8-10), requiring excellent cooperation between various surgical and medical specialties, anesthesia and intensive care, nutrition, nursing team, psychologists, kinesi-therapy, medical rehabilitation (11), ergotherapy, social assistance. At the core of this team sits a powerful duo composed of an anesthetist and a surgeon, coordinating and planning the collective efforts. While management of extensive or special burns is usually done in specialized centers, the vast majority of burn patients does not require admittance to such centers or are suitable for ambulatory treatment. Thus, besides some emergency maneuvers to be mastered by every surgeon (fasciotomy, etc.) it is common for surgeons to treat small burns.

To obtain reliable epidemiological data, paramount in planning and managing a nationwide burn care network, some countries have implemented a burn database (12-15) (the United Kingdom, France, Germany, United States of America, the Netherlands, Australia, Japan). Romania has a national data collecting mechanism regarding all hospitalized patients, but there are no available statistics concerning non-hospitalized burn cases.

The purpose of this study is to explore the amplitude of burns in Romania by analyzing 1-year data from the Emergency Department of the largest adult hospital in the region of Moldova.

\section{Material and Methods}

This is a retrospective single-center 1-year study of all burn-related emergency department presentations from January 1st to December $31^{\text {st }}, 2015$. Included in the study were all cases of burns, indiscriminate of their etiology (flame, 
scald, electrocution, contact, chemicals, explosions, sun exposure).

Variables considered were age, sex, urban/ rural provenience, county of residence, month of occurrence, hospitalization, and transfer to another hospital or discharged status. Burn surface was also considered, when included in the records.

Epidemiological markers were collected from TEMPO statistics platform, Romanian National Statistics Institute (16). It considered population by residence, in the geographical area of Iaşi County and variables taken into account were age groups, sex, and urban / rural provenience.

Descriptive statistical analysis was performed using Statistical Package for the Social Sciences, IBM Corporation (IBM ${ }^{\circledR}$ SPSS $^{\circledR}$ Statistics 25).

\section{Results}

A total of 355 burn cases were treated between January $1^{\text {st }}$ and December $31^{\text {st }} 2015$. The average monthly number of cases was 29.58 , with a maximum of 54 cases in July and 48 cases in November and a minimum of 18 cases in December and January.

Out of these, $58.1 \%$ (206 cases) were males and $41.9 \%$ (149 cases) were females ( $p<$ $0.00001)$. There were a total of 205 urban residents (57.7\%) and 150 (42.3\%) rural residents.

Only $134(37.75 \%)$ cases have been admitted and hospitalized during this period. There have been no recorded burn-related deaths in the Emergency Department in the analyzed period. The average age of the patients was 44.3 years.

A total of 216 cases in the studied group had the surface of the burned area recorded in the medical records. Out of these, 109 (50.4\%) were male and 107 (49.6\%) female. There were 118 $(54.62 \%)$ urban residents, with an average age of 47.88 years old. The average burned surface was $6.92 \%$ of the total body surface area (TBSA). A number of 107 (49.5\%) of these cases were hospitalized, 102 (47.2\%) discharged home and $7(0.3 \%)$ transferred to another facility.
The most frequent cause of burns was scalding with 139 cases out of the 355 analyzed (39.15\%). Out of these, 60 cases were male $(43.16 \%)$ and 79 female (56.84\%). The hospitalization rate for this etiology was $45.32 \%$ (63 patients). The majority of patients had an urban provenience (53.9\%), while rural patients accounted for $46.1 \%$. The average scalding patient age was 49.8 years old. Average monthly presentation for scald burns was 11.58 cases per month, with peaks in July (18 cases) and November (20 cases), and a minimum in December (7 cases) and January (8 cases);

The second most frequent cause of burn presentation at the Emergency Department of St. Spiridon Hospital in 2015 was represented by chemical burns, with 103 cases, representing $29.01 \%$ of the total. Out of these, 79 cases were male $(76.69 \%)$ and only 24 cases female $(23.31 \%)$. Only 4 patients $(3.88 \%$ out of the chemical burns patients) were hospitalized. A strong urban prevalence was noted, with a $71.84 \%$ majority, compared to only $28.16 \%$ cases coming from rural areas. The average age of chemical burns cases was 35.13 years old. The average number of monthly presentations was 8.58, with high incidences in the June-November period and peaks in July (18 cases) and August (16 cases), and minimums in March and May (1 case each). There were 86 cases of ocular pepper spray injury, accounting for $83.4 \%$ of all chemical burns cases and $24.22 \%$ of all Emergency Department presentations involving burns.

There were 55 cases of burns caused by flames, with 38 male patients (69.09\%) and17 female cases (30.9\%). Out of these, only $41.81 \%$ had an urban provenience, while the majority of cases were from rural areas $(58.18 \%)$. The average age of these flame burns cases was 48.2 years old. There were 43 hospitalizations, representing $78.18 \%$ of all cases in this group. The average number of monthly presentations was 4.58 cases, with peaks in February, March (6 cases each) and April (10 cases), and minimums in June (2 cases), October and January (3 cases each).A number of 49 patients (89\%) from this group 
had the burn surface written down in their charts, and it was $12.5 \%$ in average. There were 43 hospitalizations in this group $(78.18 \%$ of flame burns cases), 10 discharged and 2 transferred patients. The discharged patients had an average age of 37.1 years, an urban-torural ratio of $1: 1$, male-to-female ratio of $9: 1$, and an average burned TBSA of $4.1 \%$. The hospitalized ones had an average age of 52.6 years, an urban-to-rural ratio of 1.15:1, maleto-female ratio of $2: 1$, and an average burned TBSA of $14 \%$.

Contact burns represented 26 cases: 13 males and 13 females, with a 57.69\% urban provenience of the patients. The average age of these patients was 47.6 years old. There were an average of 2.16 monthly presentations, with peaks in July (5 cases) and November (6 cases), and minimums in December and April (no cases). There were 9 hospitalizations, accounting for $34.6 \%$ of cases in this group.

A number of 4 electrocution cases were encountered: 2 males and 2 females, with an average age of 42.2 years. None of the cases were discharged, 1 being hospitalized and the 3 remaining transferred.

In the studied group there were 28 cases of burns with unspecified causes: 12 males $(42.8 \%)$ and 16 females (57.2\%), out of which $57.14 \%$ with an urban provenience and $42.86 \%$ rural. Their average age was 42.14 years, and there were 2.3 average monthly presentations in this group. There were 15 hospitalized cases, which represented $53.57 \%$ cases in this group.

Only $17(4.78 \%)$ cases were residents of other counties, the majority of patients residing in the county of Iaşi.

\section{Discussions}

This is the first study of burns in an Emergency Department setting, in Romania, and one of the few studies taking into account all burns, not only the ones requiring hospitalization. Despite the limitations of data collection from a single center, adult-only hospital, the results are sufficient to paint an overall picture, easily extrapolated nationwide, and to justify pursuing the clarification of this subject.

The most striking result is the fact that only $37.75 \%$ of all burns presentations to the Emergency Department were hospitalized (Fig. 1), implying that for each hospitalized case, counting towards the current national statistics, there are two other cases that are untraceable and escape this count. As a result, the number of annual burn injuries may be three times greater than the current estimate. Thus, the social and economic implications of this phenomenon cannot be fully understood, or correctly evaluated (17).

As resulted from this study, the incidence of burn cases in Iaşi County, in the adult population, in 2015, was 55.03 per 100.000 (TEMPO database national statistics show a population of 645.086 people over the age of 15 , in Iaşi County in 2015, out of the total of 787.589). If out-of-county cases are eliminated, the residence-corrected incidence is 52.39 per 100.000 .

The $\mathrm{M}: \mathrm{F}$ ratio was $1.38: 1$, similar to worldwide statistics (18), which depict a stronger male prevalence, usually explained by different work-related profiles and tendency to engage easier in risky behavior.

The urban-to-rural ratio in the studied population was $1.36: 1$, while the urban-torural ratio in the general population in Iaşi County is $1: 1.18$, with a $45.8 \%$ urban population. Comparing these data, a stronger prevalence for burn lesions is observed in the urban population of Iaşi County, a feature

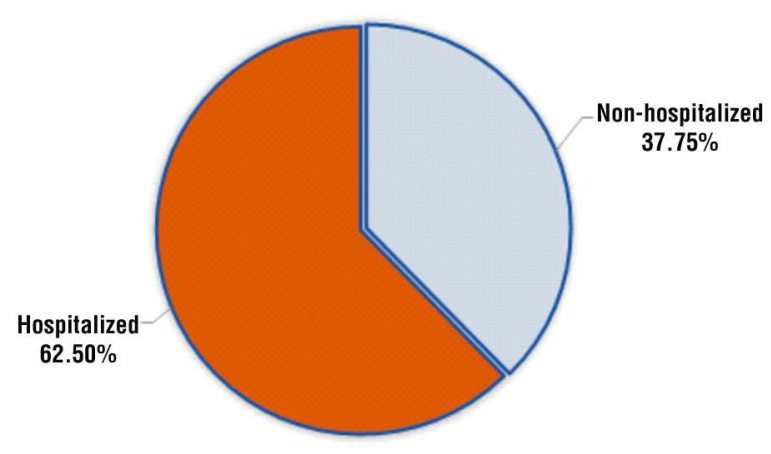

Figure 1. Percentage of hospitalized burns presentations at the emergency department 
unlike the usual epidemiological findings. This peculiar finding can partially be explained by the fact that $24.22 \%$ out of all cases included were pepper spray lesions, in a predominantly urban young male population.

Scalding represented the dominant cause of burns included in this study, data which fits into the international patterns (19). It was the populational segment with the highest average age (49.8 years vs 47.8 years in all burn cases studied) and this finding also reflects international epidemiological trends, in which scald burns are more frequent in the youngest and oldest populations.

Chemical burns represented an unlikely second most frequent cause of burns included in this study, representing almost a third of the cases $(29.01 \%)$, with a predominant young, male, urban population. This fact is easily explained by the 86 cases of ocular pepper spray burns which account for $24.22 \%$ of all cases included in this study. Although rarely described in burn textbooks, this type of lesion is frequently included in the epidemiological statistics because of its chemical mechanism.

Flame burns were only the third most frequent cause of burns in the Emergency Department but had the highest percentage of hospitalizations $(78.18 \%)$. The discharged patients had an average age of 37.1 years and an average burned TBSA of $4.1 \%$, while the hospitalized ones had an average age of 52.6 years and an average burned TBSA of $14 \%$. These data explain (20) the need for hospitalization of this older population, with a larger burned TBSA.

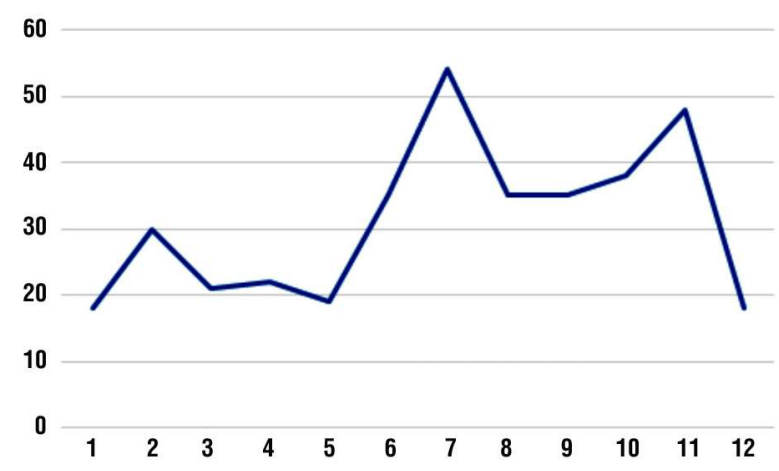

Figure 2. Monthly Distribution of burn presentations

Monthly distribution (Fig. 2) follows classically described patterns with two distinct periods of high frequency, during the summer and winter months. Some regional characteristics can be seen: a high frequency of flame burns in spring, when people burn vegetal residues after garden or agricultural cleaning or the high number of cement chemical burns during summer months in construction workers not wearing adequate protection.

Because burn surface was recorded in only 216 cases, conclusions regarding the number of burn center beds necessary in this region cannot be drawn. Despite this, the necessity of a burn center in this geographical area is obvious, as it serves the largest populational province (Moldova represents 18\% of Romania's Population) and neighboring counties refer cases to Iaşi because it is a tertiary care center. Analysis of the obtained data shows that out of the cases with a burned TBSA recorded, 32 had above or equal 10\% TBSA (Fig. 3).

Figure 3. Distribution of burn size (\% TBSA) in the studied group

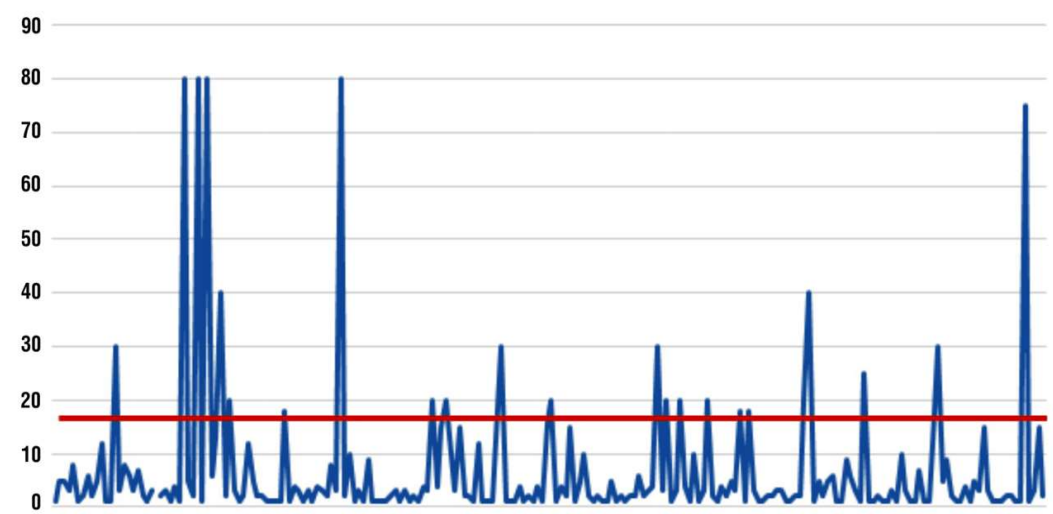


According to international standards these should be considered for admission in a type of burn care facility. Going into detail, we know that 19 of them had above or equal $20 \%$ TBSA, out of which 11 had above or equal $30 \%$ TBSA. These types of burns should be considered for admission in a burn unit. However, the most severe cases $(7$ had above or equal $40 \%$ TBSA out of which 5 had above or equal $50 \%$ TBSA) should be treated in highly specialized burn centers. This data alone shows the need for a burn center but is not precise enough to quantify this need.

\section{Conclusions}

This is the first study of burns in an Emergency Department in Romania. It focuses on the Emergency Department of St. Spiridon Hospital in Iaşi, the main adult hospital in the second-largest county of the country, analyzing the 1-year situation between January $1^{\text {st }}$ and December $31^{\text {st }}$, 2015.

Almost a quarter (24.22\%) of cases was represented by pepper spray lesions in a young male urban population. This finding should raise questions concerning legislation $(21,22)$ regulating the purchase and use of such sprays, as well as their ingredients.

Almost two-thirds of cases in this study have not been hospitalized and are absent from national healthcare statistics. Avoiding loss of data is important to obtain precise epidemiological information, paramount to formulating a national burn management strategy. In this regard, we suggest the implementation of a national burn registry.

\section{Acknowledgements}

The authors wish to thank the Emergency Department of St. Spiridon Hospital, Iaşi, Romania for access to their database and the Romanian National Statistics Institute TEMPO online platform, for the use of its public population data.

\section{Conflict of Interest Statement}

The authors of this study declare there are no conflicts of interest.

\section{References}

1. Michale DP. Epidemiology and prevention of burns throughout the world. In: Jeschke MJ, Kamolz LP, Sjoberg F, Wolf SE, editors. Handbook of burns Volume 1, Acute Burn Care. Vienna: Springer; 2012. p 19-60.

2. Murray CJL. Global, regional, and national incidence, prevalence, and years lived with disability for 354 diseases and injuries for 195 countries and territories, 1990-2017: a systematic analysis for the Global Burden of Disease Study 2017. Lancet. 2018; 392:1789-858.

3. Peck MD, Toppi JT. Epidemiology and prevention of burns throughout the world. In: Jeschke MJ, Kamolz LP, Sjoberg F, Wolf SE, editors. Handbook of burns Volume 1, Acute Burn Care, 2nd Edition. Vienna: Springer; 2020. p 17-58.

4. Brusselaers N, Monstrey S, Vogelaers D, Hoste E, Blot S. Severe burn injury in Europe: a systematic review of the incidence, etiology, morbidity, and mortality. Critical Care. 2010;14(5):R188.

5. Pruitt BA Jr, Wolf SE, Mason AD Jr. Epidemiological, demographic, and outcome characteristics of burn injury. In: Herndon DN, editor. Total Burn Care, 4th Edition,. New York: Elsevier Saunders; 2012. p 15-46.

6. Steinstraesser L, Al-Benna S. Acute management of burn/electrical injuries. In: Neligan PC, editor. Plastic Surgery. 3rd Edition, Volume 4. New York: Elsevier Saunders; 2013. p 393-434.

7. World Health Organisation, Burns, Key Facts. (Internet) 2018 (cited 2020, February 1). Available from: https://www.who.int/newsroom/fact-sheets/detail/burns

8. Brychta P, Magnette A. European Practice Guidelines for Burn Care Version 1 (Minimum Level of Burn Care Provision in Europe). European Burns Association (Internet). 2011 (cited 2020, February 1) (about 49p). Available from: https://tkmu.tbzmed.ac.ir/uploads/127/ CMS/user/file/815/EBAGuidelinesBurnCareVersion1\%20IMMP.pdf

9. Beerthuizen G, Magnette A. European Practice Guidelines for Burn Care Version 2 (Minimum Level of Burn Care Provision in Europe). European Burns Association (Internet). 2013 (cited 2020, February 1) (about $84 \mathrm{p}$ ). Available from: https://www.academia.edu/ 9432606/European_Burns_Association_European_Practice_Guide lines_for_Burn_Care_Minimum_level_of_Burn_Care_Provision_in Europe

10. Beerthuizen G, Magnette A, et al. European Practice Guidelines for Burn Care Version 2 (Minimum Level of Burn Care Provision in Europe). European Burns Association (Internet). 2017 (cited 2020, February 1) (about 147p). Available from: https://www.euroburn. org/wp-content/uploads/EBA-Guidelines-Version-4-2017.pdf

11. Langkust J. Organisation sanitaire de la filière régionale et résultats des brulures profondes de la main chez l'enfant. Faculte de Medecine de Nancy (Internet). 2014 (cited 2020, February 1) (about 108p). Available from: https://hal.univ-lorraine.fr/ hal-01733231/document

12. Mosier MJ, et al. National burn repository 2017 Update. Report of data from 2008 - 2017. American Burn Association (Internet). 2017 (cited 2020, February 1) (about 141p). Available from: https://cdn.ymaws.com/ameriburn.site-ym.com/resource/collection/4C72F10C-24FD-401C-8608-417BFAB10138/2017_ ABA_NBR_Annual_Report.pdf 
13. Pasquereau A, Thélot B. Epidémiologie des hospitalisations pour brûlures en France : résultats 2012 et perspectives. Rev Epidémiol Santé Publique. 2015;63 Suppl 1:S28.

14. Verbrennungsstatistik 2012. Deutsche Gesellschaft fur Verbrennungsmedizin (Internet). 2012 (cited 2019, December 25). Available from https://www.verbrennungsmedizin.de/files/dgv_files /pdf/verbrennungsstatistiken/Verbrennungsstatistik-2012.pdf

15. Dokter J, Vloemans AF, Beerthuizen GIJM, van der Vlies CH, Boxma $\mathrm{H}$, Breederveld $\mathrm{R}$ et al. Epidemiology and trends in severe burns in the Netherlands. Burns. 2014;40(7):1406-14.

16. Baze de date statistice. Institutul National de Statistica, http:// statistici.insse.ro:8077/tempo-online/\#/pages/tables/insse-table

17. Schneider JC, Chen L, Simko LC. Challenges to the standardization of burn data collection: a call for common data elements for burn care. J Burn Care Res. 2018;39:201-208.
18. Wolf SE, Cancio LC, Pruitt BA. Epidemiological, Demographic and Outcome Characteristics of Burns. In Herndon DN, editor. Total Burn Care, 5th Edition. New York: Elsevier Saunders; 2018. p 16-27.

19. Smolle C, Cambasio-Daniel J, Forbes AA, Wurzer P, Hundeshagen $G$, Branski LK et al. Recent trends in burn epidemiology worldwide: A Systematic Review. Burns. 2017; 43(2):249-257.

20. Peck M, Pressman MA. The correlation between burn mortality rates from fire and flame and economic status of countries. Burns. 2013;39:1054-1059

21. Peleg K, Goldman S, Sikron F. Burn prevention programs for children: do they reduce burn-related hospitalizations?. Burns. 2005;31(3):347-350.

22. Liao C-C, Rossignol AM. Landmarks in burn prevention. Burns. 2000;26(5):422-34. 